\title{
Serum potassium and calcium level in patients with post myocardial infarction ventricular fibrillation
}

\author{
Zainab A. Mahmood ${ }^{1}$ \\ 1 M.B.Ch.B., F.I.B.M.S, Department of Medicine, College of Medicine, University of Basrah \\ Received: 18.01.2021 \\ Accepted: 09.05.2021
}

\begin{abstract}
Background: Arrhythmias are common in the first hours after myocardial infarction. Electrolytes imbalance often contribute to the development of cardiac arrhythmias. Aims of the study to show the correlation between serum potassium and calcium and development of post myocardial infarction ventricular fibrillation and to assess the effect of different age groups and gender in the development of this arrhythmia.

Methods: Ninety-three patients, 66(70.96\%) males and 27 (29\%) females were studied. The mean age was 57.13 \pm 11.86 years. Patients included were those who were admitted to the cardiac care units with acute myocardial infarction in 4 hospitals in Basra (southern of Iraq), blood samples for Potassium and Calcium were taken upon admission.

Results: Forty (43\%) patients had developed primary ventricular fibrillation. The incidence of primary ventricular fibrillation was greater among patients with serum Potassium $\leq 3.5 \mathrm{mmol} / \mathrm{L}$ and $>4.5 \mathrm{mmol} / \mathrm{L}$ ( $\mathrm{p}$ value $=0.002$ ). Age was not associated with increased frequency of primary ventricular fibrillation in patients with abnormal serum Potassium, but the incidence of primary ventricular fibrillation as caused by abnormal serum Potassium level was higher among females. No increase in primary ventricular fibrillation was found in patients with abnormal serum Calcium.

Conclusion: The incidence of post myocardial ischemic primary ventricular fibrillation was very common in patients with serum Potassium $\leq 3.5 \mathrm{mmo} / \mathrm{L}$ and $>4.5 \mathrm{mmol} / \mathrm{L}$.
\end{abstract}

Keywords: myocardial infarction, serum potassium, serum calcium.

Corresponding to:

Zainab A. Mahmood, Department of Medicine, College of Medicine, University of Basrah, Basrah, Iraq

\section{zainab albahrani2000@yahoo.com}

\section{Introduction}

About $90 \%$ of patients who have an acute myocardial infarction (AMI) develop some form of cardiac arrhythmias during or immediately after the event. In $25 \%$ of patients, such rhythm abnormalities manifest within the first 24 hours. In this group of patients, the risk of serious arrhythmias, such as ventricular fibrillation, is greatest in the first hour and declines thereafter. The incidence of arrhythmia is higher with an STelevation myocardial infarction (STEMI) and lower with a non-ST-elevation myocardial infarction (NSTEMI). ${ }^{1 .}$

The incidence of primary ventricular fibrillation is greatest in the first hours after the onset of infarction $(4.5 \%)$ and declines rapidly thereafter. Approximately $60 \%$ of episodes occur within 4 hours, and $80 \%$ occur within 12 hours. $^{2}$

Primary ventricular fibrillation (PVF) during acute myocardial infarction (AMI) is conventionally defined as ventricular fibrillation that is not preceded by signs or symptoms of 
heart failure or cardiogenic shock. PVF is the most frequent cause of death related to AMI because it often occurs before monitoring. ${ }^{3}$

Potassium plays an essential role in maintaining myocardial electrical stability. In the setting of myocardial ischemia, adrenergic stimulation activates the Na-K ATPase pump, lowering plasma potassium levels. ${ }^{4}$ As a result, both professional guidelines and experts have recommended a target potassium level of at least $4.0 \mathrm{mEq} / \mathrm{L}$ in the setting of acute coronary syndrome (ACS).$^{5-7}$

Calcium is involved in the physiological and biochemical processes of heart electrophysiology and contraction, blood coagulation, neurotransmitter release, enzyme activity regulation, and blood pressure regulation. ${ }^{8,9}$

\section{Methods}

This is a cross-sectional study. A total of 93 patients, 66(70.96\%) males whose ages ranged between 25-90years (mean 57.5 years), and $27(29 \%)$ females whose ages ranged between 35 81years (mean 58years), were included in 18 months study conducted from the 9 th of December 2015 to the 9th of June 2017.

Primary VF in this study refers to fibrillation occurring in the absence of shock or pulmonary edema.

According to the age, patients were classified in to; young age (25-45years), middle age (4665years) and old age ( $>65$ years) groups.

As for S.K level, patients were classified as having abnormal S.K (low or high) $(\leq 3.5 \mathrm{mmol} / \mathrm{L}$ or $>4.5 \mathrm{mmol} / \mathrm{L}$ respectively), and normal S.K (3.6-4.5mmol/L).

According to S.Ca level, patients were classified in to; those with low S.Ca $(<2 \mathrm{mmol} / \mathrm{L})$, normal S.Ca (2-2.6mmol/L), and high S.Ca $>2.6 \mathrm{mmol} / \mathrm{L}$. Inclusion criteria:
Patients included in this study were those who were admitted to the cardiac care unit of $\mathrm{Al}$ Basrah General Hospital, Al Faihaa General Hospital and Al Sadir Teaching Hospital and diagnosed as acute myocardial infarction according to criteria that made by ACCF/AHA Guideline in 2013 [10] and AHA/ACC Guideline in 2014 [11].

Blood samples were taken from all patients with acute MI (STEMI and NSTEMI) to measure serum electrolytes ( $\mathrm{K}$ and $\mathrm{Ca}$ ) at the time of admission. Samples were collected using plan tube and analyzed by Architect plus machine. Patients who had developed VF on admission, blood samples for electrolytes were taken just after successful resuscitation.

Exclusion criteria: patients excluded were those with:

-Evidence of left ventricular dysfunction either clinically or by echocardiography.

- Cardiogenic shock.

-Non survival post AMI primary-VF

\section{Statistical analysis}

All data were analyzed by SPSS (Statistical Package for Social Science - version 15). P value $<0.05$ was considered to be significant.

\section{Results}

Table 1 show the demographic features for both groups of patients. There were no significant differences among patients who developed VF (cases) from those who didn't (control). The mean age for the cases was $57.13 \pm 11.86$ years.

Twenty five percent of the patients who developed VF had hypertension, and $22.5 \%$ had DM. Twenty five percent of the cases had previous attacks of IHD and there was no significant difference between them and those who didn't developed VF. 


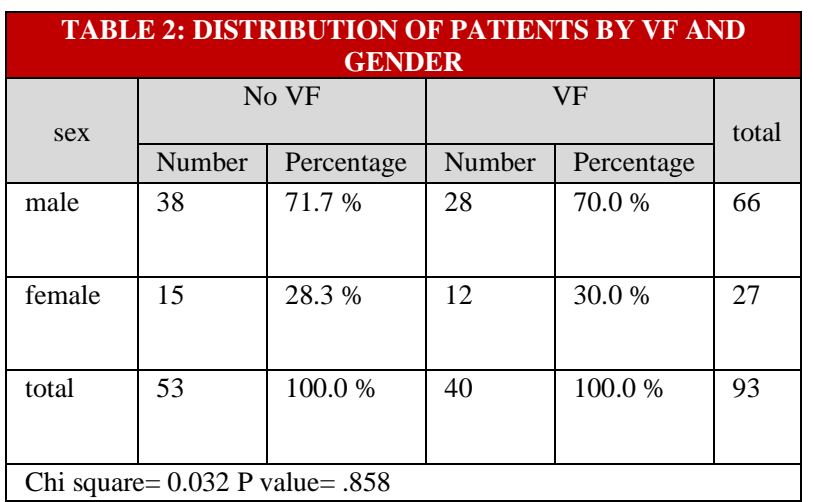

\begin{tabular}{|c|c|c|c|}
\hline \multicolumn{3}{|c|}{ TABLE 1: DEMOGRAPHIC FEATURES FOR CASES AND } \\
\hline Variable & $\begin{array}{c}\text { Patients with } \\
\text { VF } 40 \\
\text { N }(\%)\end{array}$ & $\begin{array}{c}\text { Patients } \\
\text { without VF } 53 \\
\text { N }(\%)\end{array}$ & P value \\
\hline Age & $57.13 \pm 11.86$ & $61.38 \pm 14.49$ & 0.13 \\
Mean \pm SD \\
(years)
\end{tabular}

From a total of 93patients, 40(43\%) developed VF; $28(70 \%)$ of them were males, while from 53(56.98\%) didn't develop VF; 38(71.7\%) were males. [Table 2]

So the probability of post AMI- primary VF was equal among patients regardless of gender ( $p$ value $=.858)$.
There was no statistical difference among patients who developed VF and those who didn't regarding the site of acute MI [table 3].

\begin{tabular}{|c|c|c|c|c|}
\hline \multirow{2}{*}{$\begin{array}{c}\text { Site of } \\
\text { acute MI }\end{array}$} & \multicolumn{2}{|c|}{ No VF } & \multicolumn{2}{|c|}{ VF } \\
\hline & No. & $\%$ & No. & $\%$ \\
\hline Anterior & 11 & 20.8 & 8 & 20 \\
\hline Double wall & 3 & 5.7 & 2 & 5 \\
\hline Extensive & 14 & 26.4 & 14 & 35 \\
\hline Inferior & 20 & 37.7 & 13 & 32.5 \\
\hline Lateral & 5 & 9.4 & 1 & 2.5 \\
\hline NSTEMI & 0 & 0 & 2 & 5 \\
\hline Total & 53 & & 40 & \\
\hline
\end{tabular}

From table 4 it was clear that most patients who developed post AMI-primary VF had low S.K (22(55\%)) patients, also the percentage of post AMI-primary VF in patients who had abnormal high S.K level constituted $25 \%$ compared to $28.3 \%$ of those who didn't developed VF. The overall association between risk of post AMIprimary VF and S.K level was statistically significant $(\mathrm{p}$ value $=.002)$. 
The Medical Journal of Basrah University

(2021); 39(1): 47- 53

\begin{tabular}{|c|c|c|c|c|}
\hline \multirow{2}{*}{$\mathrm{S} . \mathrm{K}(\mathrm{mmol} / \mathrm{L})$} & \multicolumn{2}{|c|}{ No VF } & \multicolumn{2}{|c|}{ VF } \\
\hline & No. & $\%$ & No. & $\%$ \\
\hline$<3$ & 0 & 0.0 & 4 & 10.0 \\
\hline $3-3.5$ & 10 & 18.9 & 18 & 45.0 \\
\hline $3.6-4$ & 18 & 34.0 & 7 & 17.5 \\
\hline $4.1-4.5$ & 10 & 18.9 & 1 & 2.5 \\
\hline $4.6-5$ & 8 & 15.1 & 7 & 17.5 \\
\hline$>5$ & 7 & 13.2 & 3 & 7.5 \\
\hline total & 53 & 100.0 & 40 & 100.0 \\
\hline hi saure- & 04 & .002 & & \\
\hline
\end{tabular}

This study had shown an interesting finding that abnormal S.K induced post AMI-primary VF significantly affected females (11(91.6\%)) patients, $p$ value $=.017)$. [Table 5]

\begin{tabular}{|c|c|c|c|c|c|c|c|c|}
\hline \multicolumn{9}{|c|}{$\begin{array}{l}\text { TABLE 5: VENTRICULAR FIBRILLATION ANI } \\
\text { SERUM POTASSIUM LEVEL AND GENDER }\end{array}$} \\
\hline \multicolumn{2}{|c|}{$\begin{array}{l}\text { S.k }(\mathrm{mmol} / \mathrm{L}) \\
\text { Gender }\end{array}$} & $<3$ & $3-3.5$ & $\begin{array}{c}3.6 \\
4\end{array}$ & $\begin{array}{l}4.1- \\
4.5\end{array}$ & $\begin{array}{c}4.6- \\
5\end{array}$ & $>5$ & $\frac{\mathscr{0}}{\frac{\pi}{\pi}}$ \\
\hline \multirow[t]{2}{*}{ male } & $\begin{array}{l}\text { No } \\
\text { VF }\end{array}$ & $\begin{array}{ll}0 \\
0 \%\end{array}$ & $\begin{array}{l}9 \\
23.7 \\
\%\end{array}$ & $\begin{array}{l}11 \\
28.9 \\
\%\end{array}$ & $\begin{array}{l}7 \\
18.4 \\
\%\end{array}$ & $\begin{array}{l}7 \\
18.4 \\
\%\end{array}$ & $\begin{array}{l}4 \\
10 . \\
5 \%\end{array}$ & \multirow[t]{2}{*}{.058} \\
\hline & $\mathrm{VF}$ & $\begin{array}{l}3 \\
10.7 \\
\%\end{array}$ & $\begin{array}{l}13 \\
46.4 \\
\%\end{array}$ & $\begin{array}{l}6 \\
21.4 \\
\%\end{array}$ & $\begin{array}{l}1 \\
3.6 \\
\%\end{array}$ & $\begin{array}{l}3 \\
10.7 \\
\%\end{array}$ & $\begin{array}{l}2 \\
7.1 \\
\%\end{array}$ & \\
\hline \multirow[t]{2}{*}{ female } & $\begin{array}{l}\text { No } \\
\text { VF }\end{array}$ & $\begin{array}{ll}0 \\
0 \%\end{array}$ & $\begin{array}{ll}1 \\
6.7 \%\end{array}$ & $\begin{array}{l}7 \\
46.7 \\
\%\end{array}$ & $\begin{array}{l}3 \\
20 \\
\%\end{array}$ & $\begin{array}{l}1 \\
6.7 \\
\%\end{array}$ & $\begin{array}{l}3 \\
20 \\
\%\end{array}$ & \multirow[t]{2}{*}{.017} \\
\hline & $\mathrm{VF}$ & $\begin{array}{l}1 \\
8.3 \\
\%\end{array}$ & $\begin{array}{l}5 \\
41.7 \\
\%\end{array}$ & $\begin{array}{l}1 \\
8.3 \\
\%\end{array}$ & $\begin{array}{l}0 \\
0.0 \\
\%\end{array}$ & $\begin{array}{l}4 \\
33.3 \\
\%\end{array}$ & $\begin{array}{l}1 \\
8.3 \\
\%\end{array}$ & \\
\hline
\end{tabular}

This study had shown no statistically significant difference in development of post AMI-primary VF in patients with abnormal (high or low) S.K among different age groups ( $p$ value $=.199$ in
Serum potassium and calcium level in patients with post myocardial infarction ventricular fibrillation

young age, .081 in middle age, and .245 in old age group). [Table 6]

\begin{tabular}{|c|c|c|c|c|c|c|c|c|}
\hline \multicolumn{9}{|c|}{$\begin{array}{l}\text { TABLE 6: VENTRICULAR FIBRILLATION AND SERUM POTASSIUM } \\
\text { LEVEL AMONG AGE GROUPS }\end{array}$} \\
\hline \multicolumn{2}{|c|}{$\begin{array}{l}\text { S.K(mmol/L) } \\
\text { Age(year) }\end{array}$} & $<3$ & $3-3.5$ & $3.6-4$ & $\begin{array}{c}4.1- \\
4.5\end{array}$ & $4.6-5$ & $>5$ & $\begin{array}{c}\mathrm{P} \\
\text { value }\end{array}$ \\
\hline \multirow[t]{3}{*}{$25-45$} & No & 0 & 2 & 2 & & & & \multirow{3}{*}{.199} \\
\hline & VF & $0.0 \%$ & $20.0 \%$ & $20.0 \%$ & $20.0 \%$ & $10.0 \%$ & $30 \%$ & \\
\hline & $\mathrm{VF}$ & $\begin{array}{l}1 \\
11.1 \%\end{array}$ & $\begin{array}{l}6 \\
66.7 \%\end{array}$ & $\begin{array}{l}1 \\
11.1 \%\end{array}$ & $\begin{array}{l}0 \\
0.0 \%\end{array}$ & $\begin{array}{l}0 \\
0.0 \%\end{array}$ & $\begin{array}{l}1 \\
11.1 \%\end{array}$ & \\
\hline \multirow[t]{4}{*}{$46-65$} & No & 0 & 4 & 10 & 5 & 2 & 2 & \multirow[t]{4}{*}{.081} \\
\hline & VF & $0.0 \%$ & $17.4 \%$ & $43.5 \%$ & $21.7 \%$ & $8.7 \%$ & $8.7 \%$ & \\
\hline & VF & & 10 & & & & & \\
\hline & & $8.0 \%$ & $40.0 \%$ & $24.0 \%$ & $4.0 \%$ & $20.0 \%$ & $4.0 \%$ & \\
\hline \multirow[t]{3}{*}{$>65$} & No & & & & & & & \multirow[t]{3}{*}{.245} \\
\hline & VF & $0.0 \%$ & $20.0 \%$ & $30.0 \%$ & $15.0 \%$ & $25.0 \%$ & $10.0 \%$ & \\
\hline & $\mathrm{VF}$ & $\begin{array}{l}1 \\
16.7 \%\end{array}$ & $\begin{array}{l}2 \\
33.3 \%\end{array}$ & $\begin{array}{l}0 \\
0.0 \%\end{array}$ & $\begin{array}{l}0 \\
0.0 \%\end{array}$ & $\begin{array}{l}2 \\
33.3 \%\end{array}$ & $\begin{array}{l}1 \\
16.7 \%\end{array}$ & \\
\hline
\end{tabular}

From the 40 patients who developed post AMIprimary VF, $10(25 \%)$ patients had low S.Ca, and $3(7.5 \%)$ patients had high S.Ca. This difference was statistically insignificant $(\mathrm{p}$ value $=.340)$. [Table 7]

\begin{tabular}{|l|l|l|l|l|}
\hline \multicolumn{5}{|c|}{ TABLE 7: VENTRICULAR FIBRILLATION AND SERUM CALCIUM } \\
\hline \multirow{2}{*}{ S.Ca(mmol/L) } & \multicolumn{2}{|c|}{ No VF } & \multicolumn{2}{c|}{ VF } \\
\cline { 2 - 5 } & No. & $\%$ & No. & $\%$ \\
\hline$<2$ & 7 & 13.2 & 10 & 25.0 \\
\hline $2-2.6$ & 42 & 79.2 & 27 & 67.0 \\
\hline$>2.6$ & & & & 7.5 \\
& 4 & 7.5 & 3 & \\
\hline total & 53 & 100.0 & 40 & 100.0 \\
\hline Chi square=2.158, P value $=.340$ & & & \\
\hline
\end{tabular}

\section{Discussion}

Potassium is the most abundant intracellular cation and is necessary for maintaining a normal charge difference between intracellular and extracellular space. The normal level of plasma potassium is $3,8-5,1 \mathrm{mmol} / \mathrm{l}$. The deviations to 
both extremes (hypo- and hyperkalemia) are related to the risk of cardiac arrhythmias ${ }^{12}$

In this study post AMI-primary VF occurs more frequently in patients with $\mathrm{S} . \mathrm{K} \leq 3.5 \mathrm{mmol} / \mathrm{L}$ and $>4.5 \mathrm{mmol} / \mathrm{L}$ this was consistent with study of Michaud, et al. ${ }^{13}$ Mia Ravn Jacobsen, et al ${ }^{14}$, and Abhinav Goyal, et al. ${ }^{15}$ who found that post MI ventricular fibrillation and mortality was more in patients with serum $\mathrm{K}<3.5 \mathrm{mmol} / \mathrm{dl}$ or $>5 \mathrm{mmol} / \mathrm{dl}$. Mia Ravn and et al. also found that highest risk of VF among patients with severe hypokalemia [2.1-2.7 $\mathrm{mmol} / \mathrm{L}]$ and the association between hypokalemia and VF may be independent of the measurement of potassium before or after VF.

Female gender was a risk factor for VF induced by abnormal S.K level; this was corresponding to the study of Vinod WaliM and Singi Yatiraj ${ }^{16}$, but inconsistent with study of Jenordrehaug, ${ }^{17}$ who found that the increased risk of VF in the abnormal S.K level was about the same for males and females.

There were no significant differences in development of post MI VF among different age groups.

Isolated abnormalities of calcium concentration produce clinically significant EP effects only when they are extreme in either direction.[18] This study had shown that; there was no significant association between post AMIprimary VF and S.Ca abnormality (p value $=.340$ ). Acute myocardial infarction affects the balance of calcium ions in the body through the metabolism of neurohormones, kidneys, and gastrointestinal tract, causing occurrence of hypocalcemia. ${ }^{19}$ To the best of our knowledge there is no other study that show the effect of serum calcium on development of post AMI primary VF, but Xingbo Gu and et al. ${ }^{20}$ found that patients with reduced serum calcium levels had a significantly higher incidence of midterm mortality, and the lowest risk of mortality was associated with approximately $2.32 \mathrm{mmol} / 1$ serum calcium and serum calcium levels added to the established risk factors model could improve the prediction of midterm mortality. Also, two studies in China reported that decreased baseline serum calcium levels were associated with a high risk of in-hospital mortality in myocardial infarction patients. ${ }^{21,22}$

In this study there was no difference in the presence of comorbidities like hypertension, DM and previous attacks of IHD in the risk of development of post AMI primary VF. This was conflicted with study of Mia Ravn and et al. ${ }^{14}$ who found that Prior myocardial infarction and diabetes mellitus was independently associated with reduced risk of VF among patients with STEMI; who explain their finding as that these patients may have more severe coronary artery disease which may influence the formation of collateral blood flow. However, this may not applicable for patients with DM.

\section{Conclusion}

Post AMI-primary VF occurs more in patients with $\mathrm{S} . \mathrm{K} \leq 3.5 \mathrm{mmol} / \mathrm{L}$ and $>4.5 \mathrm{mmol} / \mathrm{L}$, which was more common in females. The effect of calcium in development of post MI primary VF needs to be studied extensively.

Funding: This research received no grant from any funding agency in the public, commercial or not-for-profit sectors.

Conflict of interest: The authors declare no conflict of interest.

Financial Support: None declared. 


\section{References}

1. Dayan V, Soca G, Parma G, Mila R. Does early coronary artery bypass surgery improve survival in non-ST acute myocardial infarction? Interact Cardiovasc Thorac Surg. Apr 102013.

2. MacMahon S, Collins R, Peto R, Koster RW, Yusuf S. Effects of prophylactic lidocaine in suspected acute myocardial infarction. An overview of results from the randomized, controlled trials. JAMA. Oct 7 1988; 260(13):1910-6.

3. The pre-hospital management of acute heart attacks. Recommendationsof a Task Force of the European Society of Cardiology and the EuropeanResuscitation Council.Eur Heart J1998;19:1140-1164.

4. Patel, RB, Tannenbaum, S, VianaTejedor, A. Serum potassium levels, cardiac arrhythmias, and mortality following non-ST-elevation myocardial infarction or unstable angina: insights from MERLIN-TIMI 36. Eur Heart J Acute Cardiovasc Care. 2017;6(1):1825.

5. Antman EM, Anbe DT, Armstrong PW, et al. ACC/AHA guidelines for the management of patients with STelevation myocardial infarction: a report of the American College of Cardiology/American Heart Association Task Force on Practice Guidelines (Committee to Revise the 1999 Guidelines for the Management of Patients with Acute Myocardial Infarction) Circulation. 2004;110:e82292.

6. Cohn JN, Kowey PR, Whelton PK, et al. New guidelines for potassium replacement in clinical practice: a contemporary review by the National Council on Potassium in Clinical
Practice. Arch Intern Med. 2000;160:2429-2436.

7. Macdonald JE, Struthers AD. What is the optimal serum potassium level in cardiovascular patients? J Am Coll Cardiol. 2004;43:155-161.)

8. G. Santulli and A. Marks, "Essential roles of intracellular calcium release channels in muscle, brain, metabolism, and aging," Current Molecular Pharmacology, vol. 8, no. 2, pp. 206-222, 2015.

9. D. Eisner, E. Bode, L. Venetucci, and A. Trafford, "Calcium flux balance in the heart," Journal of Molecular and Cellular Cardiology, vol. 58, pp. 110-117, 2013.)

10. Patrick T. O'Gara, Frederick G. Kushner, Deborah D. Ascheim, et al. 2013 ACCF/AHA Guideline for the Management of ST-Elevation Myocardial Infarction. Circulation. Volume 127, Issue 4, 29 January 2013, Pages e362e425

11. Ezra A. Amsterdam, Nanette K. Wenger, Ralph G. Brindis, et al. 2014 AHA/ACC Guideline for the Management of Patients With Non-ST-Elevation Acute Coronary Syndromes. Circulation. Volume 130, Issue 25, December 2014, Pages e344e426.

12. Prof. Petr Widimsky. Hypokalemia and the heart. e-Journal of Cardiology Practice. Vol. 7, No. 9 - 12 Nov 2008.

13. G F Michaud, C Sticherling, $\mathrm{H}$ Tada, $\mathrm{H}$ Oral, F Pelosi Jr, B P Knight, F Morady, S A Strickberger, Relationship between serum potassium concentration and risk of recurrent ventricular tachycardia or ventricular fibrillation. $\mathrm{J}$ Cardiovasc Electrophysiol. 2001 Oct;12(10):110912.

14. Mia Ravn Jacobsen, Reza Jabbari, Charlotte Glinge, Niels Kjær Stampe, Jawad Haider Butt, Paul Blanche, et al. Potassium Disturbances and Risk of Ventricular Fibrillation Among Patients 
With ST-Segment-Elevation Myocardial Infarction. Journal of American heart association. Vol. 9, No 4, 2020;9

15. Abhinav Goyal, John A. Spertus, Kensey Gosch, et al. Serum Potassium Levels and Mortality in Acute Myocardial Infarction. JAMA. 2012;307(2):157-164.)

16. Vinod WaliM and Singi Yatiraj. Study of Serum Sodium and Potassium in Acute Myocardial Infarction. J Clin Diagn Res. 2014 Nov; 8(11): CC07-CC09.

17. Jenordrehaug, Gvon Der Lippe. From the department of medicine, Diakonissehjemmets Sykehus, Haraldsplass, Bergen, Norway. Hypokalemia and ventricular fibrillation in acute myocardial infarction. Br heart $\mathrm{J}$ 1983;50:525-9.

18. Hoffman BF, Suckling EE. Effect of several cations on transmembrane potentials of cardiac muscle. Am J Physiol, 1956; 186: 317-324.

19. Dewenter M, von der Lieth A, Katus HA and Backs J. Calcium signaling and transcriptional regulation in cardiomyocytes. Circ Res 2017; 121: 1000-1020.

20. Xingbo Gu, Xiaotong Ding, Hongna Sun, Ningning Chenand, et al. Usefulness of Serum Calcium in the Risk Stratification of Midterm Mortality among Patients with Acute Coronary Syndrome. BioMed Research InternationalVolume 2019, Article ID 9542054, 9 pages

21. S.-d. Yan, X.-j. Liu, Y. Peng et al., "Admission serum calcium levels improve the GRACE risk score prediction of hospital mortality in patients with acute coronary syndrome," Clinical Cardiology, vol. 39, no. 9, pp. 516-523, 2016.)

22. X. Lu, Y. Wang, H. Meng et al., "Association of admission serum calcium levels and in-hospital mortality in patients with acute ST-elevated myocardial infarction: an eight-year, single-center study in China," PLoS One, vol. 9, no. 6, Article ID e99895, 2014.) 